\title{
Prevalence of HBsAg and HBV Serotypes Using Antigen Detection and PCR Methods among Human Immunodeficiency Virus Patients Accessing Healthcare in a Tertiary Healthcare Facility in Central Nigeria
}

\author{
Ajegena S. Abimiku ${ }^{1}$, Oti B. Victor ${ }^{1 *}$, Pennap R. Grace ${ }^{1}$ and Richard Moses ${ }^{2}$ \\ ${ }^{1}$ Department of Microbiology, Nasarawa State University, Keffi, Nigeria. \\ ${ }^{2}$ Department of General Laboratory, General Hospital, Garaku, Nasarawa State, Nigeria.
}

\section{Authors' contributions}

This work was carried out in collaboration between all authors. Author PRG designed the study. Author ASA wrote and managed the analyses and the literature searches. Author OBV performed the statistical analysis and wrote the first draft of the manuscript. Author RM assisted in sample collection.

All authors read and approved the final manuscript.

Article Information

DOI: $10.9734 / J A M B / 2017 / 34285$

Editor(s):

(1) Grzegorz Cieslar, Department and Clinic of Internal Diseases, Angiology and Physical Medicine, Medical University of

\section{ABSTRACT}

Hepatitis B virus (HBV) co-infection with human immunodeficiency virus is a major public health problem especially in developing countries. In a descriptive study, the prevalence of HBsAg and HBV serotypes using antigen detection and PCR methods were evaluated among HIV patients accessing healthcare in a Tertiary Healthcare Facility in Central Nigeria. After ethical clearance, blood samples were aseptically collected between January to April 2016 from 547 subjects who gave informed consent and completed self-administered questionnaire. Blood samples were analyzed using HBsAg screening kit (ACON Laboratories Inc, USA) and Nested PCR approach. The Chi-square statistical test was performed to identify possible risk factors associated with the viral seropositivity. Overall, $53(9.7 \%)$ had IgG antibodies against HBV. A higher prevalence of 
$(11.0 \%)$ was recorded in males than females (8.5\%). The study revealed highest prevalence $(20.0 \%)$ in patients aged $\leq 10$ years old. The study recorded an association between the prevalence of HBsAg in relation to the education status of the patient $(p<0.05)$. The prevalence of $\mathrm{HBsAg}$ in relation to the occupation, history of blood transfusion, locality, alcohol intake and cigarette smoking, manicure and pedicure practices, scarification marks and history of HBV vaccination did not show any statistically significant association $(p>0.05)$. Twenty HBV DNA were serotyped and 17 were found positive for 2 HBV serotypes, adw 9(45.0\%) and ayw 8(40.0\%) detected. The prevalence of HBV serotypes in relation to all risk factors studied did not show any statistically significant association $(p>0.05)$. Two of the four HBV serotypes ady and adw were found to be circulating in the studied population. General health education regarding HBV infection should be advocated by Government and Non-Governmental healthcare agencies to enlighten the population of its safety measures.

Keywords: Prevalence; HBV; HIV; serotypes; Keffi.

\section{INTRODUCTION}

Hepatitis B virus (HBV) belongs to the family Hepadnaviridae and is known to have a very high transmissibility [1]. Hepatitis B virus infects the liver of hominoidae including humans and causes an inflammation called hepatitis. The disease was originally known as "serum hepatitis and is endemic in part of Asia and Africa [2]. Hepatitis is an inflammation of the liver with symptoms including yellowing of the skin and eyes (jaundice), dark urine, extreme fatigue, vomiting, abdominal pain, and rarely death [2]. It is usually caused by viral infections, toxic agents, drugs, or bacterial infections [3], but may also be due to auto immune response. Viral hepatitis has emerged as major public health problem throughout the world affecting several millions of people. It is responsible for considerable morbidity and mortality in the human population worldwide [4]. It is a major cause of liver disease morbidity and mortality worldwide, accounting for over 360 million cases of chronic hepatitis and 620,000 deaths per year [5]. It is hyper-endemic (i.e. $>8 \%$ of the population infected) in SubSaharan Africa and a major cause of chronic liver disease [6,5].

Hepatitis B virus is $50-100$ more times infectious than HIV and 10 times more infectious than $\mathrm{HCV}$, with many carriers not realizing they are infected with the virus and thus referred to as a "silent killer" [7]. Because it replicates profusely and produces a high titre in blood $\left(10^{8}-10^{10}\right.$ virions $\left./ \mathrm{mL}\right)$, any parenteral or mucosal exposure to infected blood poses a high risk of the viral acquisition [8].

Globally, more than two billion people alive today have been infected with HBV at some time in their lives. Of these, about $350-400$ million are chronic carriers and tens of millions of new cases occur annually. Of those infected, $15-40 \%$ develops cirrhosis or hepatocellular carcinoma [9] in Africa with the carrier rate varying from 9$20 \%$ in Sub Saharan Africa [10].

The clinical course of hepatitis $B$ virus infection is complex and is influenced by several factors classified into viral and host factors. The viral factors include level of hepatitis B virus replication (viral load), hepatitis $B$ virus genotype, and mutations in the viral genome. The host factors include age of acquisition of infection, immune status, concurrent infection with other hepato-tropic viruses, and alcohol intake [11].

HBV related mortality has been drastically reduced with the expanded and wide use of antiretroviral therapy (ART). However, this improved survival of HIV positive individuals created an enabling condition for the hepatitis $B$ virus to establish chronic infection and become a major cause of co-mortality in HIV/AIDS infected individuals [12].

The most efficient way to control hepatitis $B$ is to prevent individuals from contracting it rather than treat the infection. Two main approaches can lead to achieving this goal: interrupting the virus at the various routes of transmission and immunizing susceptible hosts. Although immunization is more effective, public health measures should include both approaches [13].

To date, Nigeria remains one of the endemic nations of the world whose citizen's health is being challenged with hepatitis $B$ virus infections and there is also paucity of data on serotypes of HBV infection among HIV patients in Nigeria. This study was therefore undertaken to determine the prevalence of $\mathrm{HBsAg}$ and HBV 
serotypes using antigen detection and PCR methods among HIV patients accessing healthcare in Federal Medical Centre, Keffi, Nigeria.

\section{MATERIALS AND METHODS}

\subsection{Study Area and Population}

The study area for this research was carried out in Keffi, Nasarawa State Nigeria. The town is approximately $68 \mathrm{~km}$ away from Abuja, Nigeria's Federal Capital and $128 \mathrm{~km}$ away from Lafia, the capital city of Nasarawa State. It lies between Latitude $8{ }^{\circ} \mathrm{N}$ of the Equator and Longitude $7^{\circ} 8^{\prime} \mathrm{E}$ and on an altitude of $850 \mathrm{~m}$ above the sea level [14].

The study was conducted among 547 HIV positive individuals accessing antiretroviral Therapy (ART) Clinic of the Federal Medical Centre, Keffi Nigeria who agreed to participate in the study from January through April, 2016. Their socio-demographic information was obtained by use of a designed questionnaire.

\subsection{Sample Size Determination}

The sample size for this study was determined using the formula by Yamane, [15] for sample size calculation:

$$
n=\frac{N}{1+N e^{2}}[15]
$$

Where:

$$
\begin{aligned}
& n=\text { Size of Sample } \\
& N=\text { Population Size } \\
& e=\text { Level of precision }(0.05) \\
& 1=\text { Constant } \\
& n=\frac{12438}{1+12438 \times(0.05)^{2}} \\
& n=\frac{12438}{32.095} \\
& n=387
\end{aligned}
$$

\subsection{Sample Collection}

About $2 \mathrm{ml}$ of blood sample was collected from each consenting participant by venopuncture from the antecubital veins into a labeled plain tube, and transported in a cold box to the Innovative Biotech Ltd Laboratory, Keffi. The collected samples were allowed to stand for about 5-10 minutes so as to obtain the serum. The positive samples were further preserved in cryovials and transported in ice packs to the Veterinary Teaching Hospital Laboratory Ahmadu Bello University, Zaria and stored in the refrigerator at $-20^{\circ} \mathrm{C}$ until ready for the serotyping.

\subsection{Laboratory Investigation}

\subsubsection{Screening for $\mathrm{HBsAg}$}

Screening for HBsAg from the patients' blood samples was done using (ACON Laboratories Inc, USA). The test procedure and results were carried out and interpreted according to the manufacturer's instructions.

\subsection{Polymerase Chain Reaction Method}

\subsubsection{Hepatitis B virus DNA extraction}

Twenty HBsAg positive samples were randomly selected and the viral DNA was extracted using ZR Viral RNA Kit according to the manufacturer's instructions.

\subsubsection{Buffer preparation}

Beta mercaptoethanol was added to the Viral RNA buffer to a final dilution of $0.5 \% \mathrm{v} / \mathrm{v}$. About 2 $\mathrm{ml}$ of $100 \%$ ethanol was also added to $6 \mathrm{ml}$ Viral Wash Buffer.

\subsubsection{Procedure}

Three hundred $\mu \mathrm{l}$ of prepared buffer and $300 \mu \mathrm{l}$ of the sample were mixed. Three volumes Viral DNA Buffer were added to each sample. The sample was transferred to the Zymo-Spin IC Column in a collection tube and centrifuged for 2 minutes. The flow through was discarded. $500 \mu \mathrm{l}$ Viral Wash Buffer was added to the column and centrifuged for 2 mins. The column was then carefully transferred into the DNase/RNase-free tubes and $15 \mu \mathrm{l}$ DNase/RNase-Free Water was added directly to the Column Matrix and was centrifuged for 30 seconds. The DNA was then precipitated with ethanol and dissolved with 10 $\mathrm{ml}$ of $100 \mathrm{mM}$ Tris-HCl pH 7.5, $0.1 \mathrm{mM}$ EDTA Solution. 


\subsubsection{Oligonucleotide primers}

The primer pairs used for this research work were adopted from the work of Duanthanorm et al. [16].

\subsubsection{PCR procedure}

About $12.5 \mu \mathrm{l}$ of Master Mix was added to each of the 20 DNA samples extracted. One $\mu$ l each of the forward and reverse primers was added to the mixture and $3.5 \mu \mathrm{l}$ of Nuclease Free Water was also added to the solution using a microtitre pipette. Eighteen $\mu \mathrm{l}$ of the samples was distributed to each of the PCR tubes and $7 \mu \mathrm{l}$ of the DNA templates were then added to the solution and centrifuged at $5000 \mathrm{rpm}$ for 30 secs to bring down any hanging fluid by the side or cover of the PCR tubes. Finally, it was laid over the reaction mixture. The reaction was performed in a programmable DNA Thermal Cycler for 40 cycles. One amplification cycle was consisting of denaturation for 30 seconds at $9^{\circ} \mathrm{C}$, annealing for 30 cycles at $55^{\circ} \mathrm{C}$ and extension of the annealed Oligonucleotide primers was allowed for 1 minute at $7^{\circ} \mathrm{C}$.

\subsubsection{Agarose gel electrophoresis}

Three gram agarose powder was weighed into a $100 \mathrm{ml}$ conical flask and $100 \mathrm{ml}$ of 1 X TBE Mix was added into the conical flask and dissolved in a microwave oven for 10 mins. The preparation was allowed to cool for about $45^{\circ} \mathrm{C}$. The gel casting trays were assembled and the combs were also put in place. About $5 \mu \mathrm{l}$ of Ethidium Bromide Solution was added into the conical flask and gently swirled. The combs were carefully removed from the casting trays and the tank filled to gauge mark with the $1 \mathrm{X}$ TBE running buffer. The first well was loaded with $5 \mu \mathrm{l}$ of the XbP DNA Ladder and the second loaded with $10 \mu \mathrm{l}$ nuclease free water mixed with $5 \mu \mathrm{l} 6 \mathrm{X}$ loading dye. The remaining wells were loaded with $10 \mu$ l genomic DNA samples mixed with 10 $\mu \mathrm{l}$ of the PCR amplicons. The voltage was set at $120 \mathrm{~V}$ and allowed to run for 45 mins. The gel tray was removed and transferred for observation of bands and for photographing in the computer and the results obtained were printed out.

\subsection{Ethical Approval}

Ethical clearance and approval to conduct this study was sought and obtained from the Health
Research Ethics Committee of Federal Medical Centre, Keffi, Nasarawa State on the $12^{\text {th }}$ October, 2015.

\subsection{Statistical Analysis}

Chi Square $\left(\chi^{2}\right)$ statistical test was used to test for the significance using IBM SPSS Version 20. The statistical significance was determined at $p \leq$ 0.05 level of significance.

\section{RESULTS}

Five hundred and forty seven consented HIV patients were recruited for this study. Among them were 264 (48.3\%) males and $283(51.7 \%)$ females. The overall prevalence of HBsAg in these HIV population was $9.7 \%$. Males had higher infection rate for the virus $(p>0.05)$.

\section{DISCUSSION}

Five hundred and forty seven HIV patients accessing healthcare at Federal Medical Centre, Keffi were recruited for this study. The overall prevalence of $9.7 \% \mathrm{HBV}$ infection recorded in this study was lower than prevalence rates observed in studies carried out in other parts of Nigeria. It was $10.67 \%$ in Bayelsa [17], $15.5 \%$ in Benin City [18] and $17.1 \%$ among female sex workers in Nigeria [19]. Lower rates of 9.5\% [20] and $9.2 \%$ [1] were observed in Abuja among antenatal patients and Zaria among students respectively. Several studies on the prevalence of HBsAg in different countries of the world have also shown different rates. For example, $12.3 \%$ in Ghana [21], 5.9\% in Ethiopia [12], $7.0 \%$ in South Africa and Botswana [22], 3.75\% in Tripura [23], 3.52\% and $2.7 \%$ in India [24], $7.0 \%$ in Tanzania [25] and3.0\% in Iran [26]. These differences might be as a result of different screening methods, environmental and climatic factors and socio-demographic status of the study population.

The higher rate of $\mathrm{HBsAg}$ seropositivity among males $(11.0 \%)$ than their female counterparts $(8.5 \%)(p>0.05)$ reported in this study was similar to other Nigerian studies $[18,27]$ but was in contrast with the report in Ethiopia [28]. Gender has been noted to have little or no influence on the spread of HBV infection [29]. 
Table 1. The Prevalence of HBsAg in relation to possible risk factors among HIV positive patients accessing healthcare in Federal Medical Centre, Keffi, Nigeria

\begin{tabular}{|c|c|c|c|}
\hline Risk factors & $\begin{array}{l}\text { No. } \\
\text { Examined }\end{array}$ & $\begin{array}{l}\text { No. Positive } \\
(\%)\end{array}$ & $\begin{array}{l}\mathbf{p} \\
\text { value }\end{array}$ \\
\hline \multicolumn{4}{|l|}{ Gender } \\
\hline Male & 264 & $29(11.0)$ & 0.323 \\
\hline Female & 283 & $24(8.5)$ & \\
\hline \multicolumn{4}{|l|}{ Age (Years) } \\
\hline$\leq 10$ & 10 & $2(20.0)$ & \\
\hline $11-20$ & 64 & $8(12.5)$ & \\
\hline $21-30$ & 156 & $16(10.3)$ & 0.642 \\
\hline $31-40$ & 174 & $14(8.0)$ & \\
\hline $41-50$ & 111 & $12(10.8)$ & \\
\hline$\geq 51$ & 32 & $1(3.1)$ & \\
\hline \multicolumn{4}{|c|}{ Marital status } \\
\hline Single & 223 & $24(10.8)$ & \\
\hline Married & 307 & $26(8.5)$ & 0.261 \\
\hline Divorced & 17 & $3(17.6)$ & \\
\hline \multicolumn{4}{|c|}{ Educational status } \\
\hline Primary & 21 & $3(14.3)$ & \\
\hline Secondary & 253 & $25(9.9)$ & 0.001 \\
\hline Tertiary & 273 & $25(9.2)$ & \\
\hline \multicolumn{4}{|l|}{ Occupation } \\
\hline Students & 91 & $13(14.3)$ & \\
\hline Farmers & 189 & $13(6.3)$ & \\
\hline Unemployed & 136 & $15(11.0)$ & 0.381 \\
\hline Artisans & 75 & $7(9.3)$ & \\
\hline Civil servants & 56 & $5(8.9)$ & \\
\hline \multicolumn{4}{|c|}{ History of blood transfusion } \\
\hline Yes & 125 & $8(6.4)$ & 0.158 \\
\hline No & 422 & $45(10.7)$ & \\
\hline \multicolumn{4}{|l|}{ Locality } \\
\hline Urban & 302 & $24(7.9)$ & 0.127 \\
\hline \multirow{2}{*}{\multicolumn{4}{|c|}{ Alcoholism }} \\
\hline & & & \\
\hline Yes & 275 & $28(10.2)$ & 0.696 \\
\hline No & 272 & $25(9.2)$ & \\
\hline \multicolumn{4}{|c|}{ Cigarette smoking } \\
\hline Yes & 28 & $5(17.9)$ & 0.134 \\
\hline No & 519 & $48(9.2)$ & \\
\hline \multirow{2}{*}{\multicolumn{4}{|c|}{$\begin{array}{l}\text { Self- } \\
\text { Manicure }\end{array}$}} \\
\hline & & & \\
\hline Yes & 529 & $50(9.5)$ & 0.310 \\
\hline No & 18 & $3(16.7)$ & \\
\hline \multicolumn{4}{|l|}{ Self-Pedicure } \\
\hline Yes & 525 & $52(9.9)$ & 0.406 \\
\hline No & 22 & $1(4.5)$ & \\
\hline \multicolumn{4}{|c|}{ Scarification marks } \\
\hline \multicolumn{4}{|c|}{ Tribal mark } \\
\hline Yes & 55 & $4(7.3)$ & 0.524 \\
\hline No & 492 & $49(10.0)$ & \\
\hline \multicolumn{4}{|l|}{ Tattoo } \\
\hline Yes & 28 & $2(7.1)$ & 0.641 \\
\hline No & 519 & $51(9.8)$ & \\
\hline \multicolumn{4}{|c|}{ HBV vaccination } \\
\hline Yes & 339 & $44(13.0)$ & 2.000 \\
\hline No & 208 & $9(4.3)$ & \\
\hline
\end{tabular}

The distribution of HBV infection when stratified by age showed no statistically significant association $(p>0.05)$. The least infected group $(3.1 \%)$ were people aged 51 years and above. This finding is in agreement with the report of Bezabeh et al. [28] and Birku et al. [30] in Ethiopia. According to previous epidemiological studies, there has been a link between age and the prevalence of HBsAg. That indicates the age of acquiring the infection as one of the major risk factors for HBsAg positivity [31]. The reason for the high prevalence of HBsAg recorded among age group $\leq 10$ years might not be totally unconnected with mother-to-child transmission and it also supports the fact that in areas of high endemcity, infection is acquired by lack of proper immunization among individuals [32].

Similarly, the viral infection was not associated with marital status. Although, the highest prevalence was found among those divorced $(17.6 \%)$ and least prevalence among those married (8.5\%). This might not be unconnected with the fact that both viruses are mainly sexually transmitted and having multiple sexual partners among some patients or having contracted the virus from their previous spouses before their divorce [33]. This is contrary to the report of Afolabi et al. [27] in Ibadan [27].

In a related development, viral prevalence was highest among those with the lowest level of education and lowest among those with a tertiary education $(p<0.05)$, but with consistently high prevalence irrespective of educational level attained. Education has been acknowledged to be of advantage in various facets of life. It helps in making informed decision and also sourcing for useful information regarding health concerns. This finding is similar to a report from Port Harcourt, Nigeria [34]. The possible explanation to this significance could be due to the awareness of the adult patients to seminars, lecturers, conferences and other medical talks on the hepatitis B viral infection.

With reference to occupation, students recorded the highest prevalence $(14.3 \%)$, while farmers recorded the least (6.3\%). There was no statistically significant association between viral infection and occupation ( $p>0.05)$. The might be that the types of lifestyle students' lives in their various institutions and houses are questionable and such can facilitate the acquisition of both viruses.

A history of blood transfusion was also not found to be associated with the viral seropositivity ( $p>0.05)$ in the study. It was higher (10.7\%) in those with no history of blood transfusion than 
those with a history of blood transfusion (6.4\%). This outcome agrees with the reports of other researchers $[35,36,27]$. This outcome contradicts the report of Lavanya et al. [37] who reported a higher prevalence of among those with a blood transfusion history.

Table 2. The Prevalence of HBV serotypes in relation to studied risk factors among HIV positive patients accessing healthcare at Federal Medical Centre, Keffi, Nigeria

\begin{tabular}{|c|c|c|c|c|c|}
\hline \multirow[t]{2}{*}{ Risk factors } & \multirow[t]{2}{*}{ No. Examined } & \multicolumn{3}{|c|}{ HBVSerotypes } & \multirow[b]{2}{*}{ p value } \\
\hline & & $a d w(\%)$ & $p$ value & ayw (\%) & \\
\hline \multicolumn{6}{|l|}{ Gender } \\
\hline Male & 13 & $7(53.8)$ & \multirow[t]{2}{*}{0.6580} & $3(23.1)$ & \multirow[t]{2}{*}{0.4625} \\
\hline Female & 7 & $2(28.6)$ & & $5(71.4)$ & \\
\hline \multicolumn{6}{|l|}{ Age (Years) } \\
\hline$\leq 10$ & 2 & $0(0.00)$ & \multirow{3}{*}{0.7337} & $1(50.0)$ & \multirow{3}{*}{0.8645} \\
\hline $11-30$ & 10 & $3(30.0)$ & & $5(50.0)$ & \\
\hline $31-50$ & 8 & $6(75.0)$ & & $2(25.0)$ & \\
\hline \multicolumn{6}{|l|}{ Marital status } \\
\hline Single & 10 & $5(50.0)$ & \multirow{4}{*}{0.9733} & $4(40.0)$ & \multirow{3}{*}{0.9651} \\
\hline Married & 8 & $4(50.0)$ & & $3(37.5)$ & \\
\hline Divorced & 2 & $0(0.00)$ & & $1(50.0)$ & \\
\hline \multicolumn{5}{|c|}{ Educational status } & \\
\hline Primary & 2 & $1(50.0)$ & \multirow{3}{*}{0.9733} & $1(50.0)$ & \multirow{3}{*}{0.9651} \\
\hline Secondary & 8 & $4(50.0)$ & & $4(50.0)$ & \\
\hline \multirow{2}{*}{\multicolumn{6}{|c|}{ Occupation }} \\
\hline & & & & & \\
\hline Students & 6 & $2(33.3)$ & \multirow{4}{*}{0.9800} & $2(33.3)$ & \multirow{4}{*}{0.9927} \\
\hline Farmers & 6 & $3(33.3)$ & & $3(33.3)$ & \\
\hline Unemployed & 3 & $2(66.7)$ & & $1(33.3)$ & \\
\hline Artisans & 2 & $1(50.0)$ & & $0(0.00)$ & \\
\hline Civil servants & 3 & $1(33.3)$ & & $2(66.7)$ & \\
\hline \multicolumn{6}{|c|}{$\begin{array}{l}\text { History of blood } \\
\text { transfusion }\end{array}$} \\
\hline Yes & 5 & $1(20.0)$ & \multirow[t]{2}{*}{0.7188} & $2(40.0)$ & 0.9115 \\
\hline No & 15 & $8(53.3)$ & & $6(40.0)$ & \\
\hline Locality & & & & & \\
\hline Urban & 7 & $2(28.6)$ & 0.6580 & $3(42.9)$ & 0.4690 \\
\hline Rural & 13 & $7(53.3)$ & & $5(38.5)$ & \\
\hline Alcoholism & & & & & \\
\hline Yes & 10 & $4(40.0)$ & 0.9369 & $4(40.0)$ & 1.0000 \\
\hline No & 10 & $5(50.0)$ & & $4(40.0)$ & \\
\hline Cigarette sm & & & & & \\
\hline Yes & 5 & $3(60.0)$ & 0.8990 & $0(0.00)$ & 0.6595 \\
\hline No & 15 & $6(40.0)$ & & $8(53.3)$ & \\
\hline Self-manicur & & & & & \\
\hline Yes & 16 & $7(43.8)$ & 0.9625 & $8(50.0)$ & 0.7188 \\
\hline No & 4 & $2(50.0)$ & & $0(0.00)$ & \\
\hline Self-Pedicure & & & & & \\
\hline Yes & 19 & $9(47.4)$ & 0.8028 & $7(36.8)$ & 0.8110 \\
\hline No & 1 & $0(0.00)$ & & $1(100.0)$ & \\
\hline Scarification & & & & & \\
\hline Tribal mark & & & & & \\
\hline Yes & 4 & $2(50.0)$ & 0.9625 & $0(0.00)$ & 0.7188 \\
\hline No & 16 & $7(43.8)$ & & $8(50.0)$ & \\
\hline Tattoo & & & & & \\
\hline Yes & 5 & $3(60.0)$ & 0.8990 & $1(20.0)$ & 0.7373 \\
\hline No & 15 & $6(40.0)$ & & $7(46.7)$ & \\
\hline HBV vaccina & & & & & \\
\hline Yes & 11 & $6(54.5)$ & 0.8058 & $3(27.3)$ & 0.5819 \\
\hline No & 9 & $3(33.3)$ & & $5(55.6)$ & \\
\hline
\end{tabular}


The prevalence of HBV infection was higher among rural $(11.8 \%)$ than the urban participants $(7.9 \%)(p>0.05)$. This outcome correlates with the report of Birku et al. [30] in Ethiopia. There was no statistically significant association between alcoholism and cigarette smoking habit and viral infection $(p>0.05)$. Although, the infection was higher among those that drink alcohol and smoke cigarette. It contradicts the work of Bezabeh et al. [28] who reported a higher rate among those with no history of alcohol habit. Similarly, there was also no correlation observed between the viral infection prevalence and selfmanicure and pedicure practices $(p>0.05)$. Similar reports have also been reported [38].

There was no association between scarification marks and HBV infection in this study $(p>0.05)$. The infection was higher $(10.0 \%)$ among those with no tribal marks and $9.8 \%$ among those with no tattoo. This agrees with the report of Joanah et al. [38]. Similar study was reported by Kurien et al. [39] in Vellore, Tamil Nadu in which alcohol consumption, chewing tobacco, blood transfusion, tattooing and extramarital sexual behaviors did not show any association with the prevalence of HBsAg [39]. A history of HBV vaccination was also not found to be associated with the viral seropositivity $(p>0.05)$ in the study. It was $13.0 \%$ among those who had HBV vaccination and $4.3 \%$ among those who had no HBV vaccination. It is in contrast with the report of Abdawhaba and Nafi, [40].

Twenty HBV DNA were serotyped and 17 were found positive for 2 HBV serotypes, adw $9(45.0 \%)$ and ayw $8(40.0 \%)$ detected.

There was no association between the prevalence of HBV serotypes with the gender of the HIV patients in the study area $(p>0.05)$. The prevalence of serotype adw was $53.8 \%$ among males and serotype ayw was $71.4 \%$ among females respectively with a mean range of 1.71 and standard deviation of 0.483 . Similarly, there was no statistically significant association in the viral serotypes prevalence in the different age groups. It ranged from $50.0 \%$ among those aged less than 30 years to $33.0 \%$ among older ages. Mean range and standard deviation are 1.57 and 1.813 respectively.

There was also no correlation observed between the viral subtypes prevalence and either marital status or educational status. It was highest $50.0 \%$ among singles and married for serotype $a d w$ and $50.0 \%$ among divorced for serotype ayw. It was highest in both primary and secondary education (50.0\%) for $a d w$ and ayw HBV serotypes. In a related development, HBV serotypes prevalence was highest, $66.7 \%$ in serotype adw and ayw for unemployed and civil servants respectively $(p>0.05)$. With respect to history of blood transfusion, serotype adw was $53.3 \%$ among those with no history of blood transfusion and $40.0 \%$ in ayw serotype in both those with and without any history of blood transfusion $(p>0.05)$.

No association was established between HBV serotypes and locality of the participants $(p>0.05)$. It was $53.8 \%$ in serotype adw among those in the rural setting and $42.9 \%$ in serotype ayw among those in the urban setting. Similarly, the distribution of HBV serotypes in relation to alcoholism and cigarette smoking habit was not associated. Serotype adw was higher (50.0\%) among those who do not take alcohol while serotype ayw was $40.0 \%$ among both those who takes alcohol and those that do not take alcohol. With respect to cigarette smoking habit, serotype $a d w$ was $60.0 \%$ among those that smoke cigarette while serotype ayw was $53.3 \%$ among those who do not smoke cigarette.

In this study, there was no statistically significant association between the viral subtype's prevalence and self-manicure and pedicure practices. Serotype $a d w$ was $50.0 \%$ among those who do not practice self-manicure while serotype ayw was $47.4 \%$ among those that practice self-pedicure, while serotype ayw was $100.0 \%$ among those who do not practice selfpedicure. Scarification marks was also not found to be associated with the prevalence of HBV serotypes among HIV patients $(p>0.05)$. Serotype $a d w$ was higher (50.0\%) among those with a tribal mark while serotype ayw was $50.0 \%$ among those with no tribal mark. With respect to tattoo mark, serotype adw was $60.0 \%$ among those with a tattoo mark while serotype ayw was $46.7 \%$ among those with no tattoo mark. A history of HBV vaccination was not a risk factor for HBV serotype's prevalence $(p>0.05)$. The prevalence of serotype adw was higher (54.5\%) among those with a history of HBV vaccination while serotype ayw was $55.6 \%$ among those with no history of HBV vaccination.

\section{CONCLUSION}

Co-infection with HBV and HIV is still a problem in our environment, as $9.7 \%$ of these patients were seropositive for HBV infection this implies 
that the infection is highly endemic among the HIV patients based on the WHO recommendation in the studied area.

The infection was more in males than females and in patients aged less than 10 years old. Educational status was statistically significant with the viral infection $(p<0.05)$. The prevalence of $\mathrm{HBsAg}$ in relation to the occupation, history of blood transfusion, locality, alcohol intake and cigarette smoking, manicure and pedicure practices, scarification marks and history of HBV vaccination did not show any statistically significant association ( $p>0.05)$.

Two of the four HBV serotypes ady and adw were found to be circulating in the studied population. The prevalence of HBV serotypes in relation to all risk factors studied did not show any statistically significant association ( $p>0.05)$. All states in Nigeria should advocate a health policy of universal hepatitis $B$ vaccination to prevent and control HBV infection and its longterm sequel. Early treatment of $\mathrm{HBV}$ infection can prevent disease progression and its complications which represent a significant burden of care to the Nigerian healthcare system. General health education regarding the infection should be put in place by the Government and Non-Governmental healthcare organizations to enlighten the population of its safety measures.

\section{COMPETING INTERESTS}

Authors have declared that no competing interests exist.

\section{REFERENCES}

1. Isa I, Aminu M, Abdullahi SA, Sani MA, Akafyi DE. Seroprevalence of Hepatitis B virus in a tertiary institution in NorthWestern Nigeria. African Journal of Microbiology Research. 2015;9(3):171179.

2. El-Ishaq A, Mohammed FL. Prevalence of Hepatitis B surface antigen among blood donors and patients attending General Hospital, Potiskum. Extensive Journal of Applied Sciences. 2015;3(6):199-203.

3. Agarry OO, Lekwot GZ. Prevalence of Hepatitis B virus and Hepatitis $C$ virus in antenatal patients in Gwagwalada-Abuja, Nigeria. Report and Opinion. 2010;2(7):4850.

4. Al-Hegami MA, Al-Manari A, Al-Kadasse AS, Al-Gasha'a FAS, Al-Hag S, Al-Hegami
AAS. Prevalence and risk factors of hepatitis $B$ and $C$ virus infections among patients with chronic renal failure in Zabeed City, Yeme Republic. Open Journal of Medical Microbiology. 2015; 5:136-142.

5. Musa B, Busell S, Borodo MM, Samaila AA, Femi OL. Prevalence of hepatitis B virus infection in Nigeria, 2000-2013: A systematic review and meta-analysis. Nigerian Journal of Clinical Practice. 2015; 18:163-172.

6. World Health Organization. Prevention and Control of Viral Hepatitis Infection; 2013.

Available:www.who.int/topics/hepatitis/

7. Negussie A, Beyene E. Seroprevalence of Hepatitis B surface Antigenemia among pregnant women attending antenatal clinic in Jigjiga, East Ethiopia: A cross-sectional study. International Journal of Research and Review. 2016;3(2):1-7.

8. Pennap GRI, Osanga ET, Ubam A. Seroprevalence of hepatitis B surface antigen among pregnant women attending antenatal clinic in Federal Medical Center Keffi. Research Journal of Medical Sciences. 2011;5(2):80-82.

9. Akmal $\mathrm{M}$, Zulkifle $\mathrm{M}$, Arisari $\mathrm{AH}$. Assessment of awareness of hepatitis B virus infection in the patients attending Nium, Bangalore, India. International Research Journal of Pharmacy. 2015;6(3): 210-212.

10. Ballah $A D$, Babajide $A$, Abubakar $A B$, Cecilia A, Ernest E, Mohammed AB. A survey of Hepatitis $B$ and $C$ virus prevalence in human immunodeficiency virus positive patients in a tertiary institution in North Eastern Nigeria. International Journal of medical Sciences. 2012;4(1):13-18.

11. Sonth SB, Gokale S, Hadapad D, Solabannavar SS. Prevalence of hepatitis B Virus infection among Blood Donors. International Journal of Current Microbiology and Applied Sciences, 2015; 4(10):915-918.

12. Weldemhret LM, Asmelash T, Belodu R, Gebreegziabiher D. Seroprevalence of hepatitis B virus and associated risk factor among HIV positive individuals attending ART Clinic Mekelle Hospital, Tigray, Northern Ethiopia. AIDS Research and Therapy. 2016;13(6):1-7.

13. Aggarwal $P$, Kumari $S$, Kaur M, Manhas A, Bala M, Gupte S. Prevalence of hepatitis B and Hepatitis $\mathrm{C}$ infections in patients and 
healthy blood donors. Indian Journal of Microbiology Research. 2015;2(2):115119.

14. Akwa VL, Binbol NL, Markus ND. Geographical perspective of Nasarawa State. Onaivi Printing and Publishing Company, Keffi. 2007;3.

15. Yamane T. Statistics: An introductory analysis. New York: Harper and Row; 1970.

16. Duanthanorm T, Kruavon B, Jittaporn W, Chuenchit B, Paichit W, Jakkriss B, Somsak P. Subtyping of Thai Hepatitis B Virus DNA by Polymerase Chain Reaction. Journal of Science Society, Thailand. 1994;20:115-124.

17. Ochei KC, Obeagu El, Ibegi BT, Ugobo El. Odu M. Prevalence of hepatitis B and C from samples received from the various wards in Niger Delta University Teaching Hospital (NDUTH), Okolobiri for Hematological analyses. Merit Research Journals. 2016;4(4):204-209.

18. Ojide CK, Kalu EL, Ogbaini-Emevon E, Nwadike VU. Co-infections of hepatitis B and $C$ with human immunodeficiency virus among adult patients attending human immunodeficiency virus outpatients clinic in Benin City, Nigeria. Nigerian Journal of Clinical Practice. 2015;18(4):516-521.

19. Forbi JC, Onyemauwa N, Gyar SD, Oyeleye AD, Entonu P, Agwale SM. High prevalence of Hepatitis B virus among female sex workers in Nigeria. Rev Inst. Med. Trop. S. Paulo. 2008;50(4):219-221.

20. Olaitan AO, Zamani LG. Prevelance of hepatitis $B$ virus and hepatitis $C$ virus in antenatal patients in Gwagwalada-Abuja, Nigeria. Report and Opinion. 2010;2(7):4850.

21. Ofori-Asenso R, Agyeman AA. Hepatitis B in Ghana: A systematic review and metaanalysis of prevalence studies (19952015). Bio Medical Central of Infectious Diseases. 2016;16(130):1-5.

22. Matthews PC, Beloukas A, Malik A, Carison JM, Jooste P, Ogwu A, Shapiro R, Riddell L, Chen F, Luzzi G, Jaggernath $M$, Jesuthasan G, Jeffrey K, Ndung'u T, Goulder PJR, Geretti AM. Prevalence and Characteristics of Hepatitis B virus (HBV) coinfection among HIV positive women in South Africa and Botswana. Public Library of Sciences, One. 2015;1-11.

23. Bhaumik $P$, Bhattacharjee $P$, Sil SK. Hepatitis B and Hepatitis C virus coinfection among human immunodeficiency virus infected patients of Tripora. International Journal of Scientific Study. 2015;3(6):77-80.

24. Suryanarayana S, Jahnavi I, Divya A, Nagamani K, Kumar BU. Prevalence of hepatitis $B$ virus infection in sexually transmitted disease (STD) Clinic attendees. Journal of Dental and Medical Sciences. 2015;14(10):1-3.

25. Mueller A, Stoetter L, Kalluvya A, Stich A, Majinge $\mathrm{C}$, Weissbrich $\mathrm{B}$, Kasang $\mathrm{C}$. Prevalence of hepatitis $B$ infection among healthcare workers in a tertiary hospital in Tanzania. Bio Medical Central Infectious Diseases. 2015;15(386):2-9.

26. Mohammadi Z, Keshtkar A, Eghtesad S, Jeddian A, Pourfatholah AA, Maghsudlu M, Zadsar R, Mahmoudi Z, Shayanrad A, Poustchi $\mathrm{H}$, Malekzadeh $\mathrm{R}$. Epidemiological profile of Hepatitis $B$ virus infection in Iran in the past 25 years: A systematic review and meta-analysis of general population studies. Middle East Journal of Digestive Disease. 2016;8(1):516.

27. Afolabi AY, Oladipo EK, Fagbami AH. Hepatitis $B$ virus among potential blood donors in Ibadan, Nigeria. International Journal of Medicine and Medical Sciences. 2015;3(2):40-43.

28. Bezabeh $\mathrm{YH}$, Muluneh MD, Sillasie SG, Kloos H. Higher prevalence of hepatitis $B$ virus infection among ARV-exposed than naïve HIV-infected individuals in North Shewa Zone, Ethiopia. Journal of AIDS and HIV Research. 2015;7(1):10-17.

29. Ndako JA, Onwuliri EA, Adelani-Akande T, Olaolu DT, Dahunshi SO, Udo UD. Screening for hepatitis B surface antigen (HBsAg) among health care workers (HCW) in an urban community SouthSouth Nigeria. International Journal of Biology, Pharmacy and Allied Sciences. 2014;3(3):415-425.

30. Birku T, Gelaw B, Moges F, Assefa A. Prevalence of hepatitis $B$ and $C$ viruses infection among military personnel at Bahir Dar Armed Forces General Hospital, Ethiopia. Bio Medical Central Research Notes. 2015;8:737.

31. El-Magrahe $\mathrm{H}$, El-Furarah AR, El-Figih $\mathrm{K}$, El-Urshafany S, Ghenghesh KS. Maternal and neonatal seroprevalence of hepatitis $B$ surface antigen ( $\mathrm{HBsAg}$ ) in Tripoli. Journal of Infection in Developing Countries. 2010; 4(3):168-70. 
32. Aparna S, Johannes H, Rafael TM, Gerard $\mathrm{K}$, Jordis JO. Estimation of worldwide prevalence of chronic hepatitis B virus infection. A Systematic Review of data published between 1965 and 2013. Lancet. 2015;15:1-10.

33. Akyala I, Godwin O, Ishaleku D. Seroprevalence of hepatitis B and C coinfection among cohort seropositive HIV patients accessing healthcare in Nasarawa State North Central Nigeria. British Journal of Psychological Research. 2013;1(1):1524.

34. Alegbeleye JO, Nyengidiki TK, Ikimalo JI. Maternal and neonatal seroprevalence of hepatitis B surface antigen in a hospital based population in South-South, Nigeria. International Journal of Medicine and Medical Sciences. 2013;5(5):241-246.

35. Al-Rubaye A, Tariq Z, Alrubaiy L. Prevalence of hepatitis $B$ seromakers and hepatitis $\mathrm{C}$ antibodies in blood donors in Basra, Iraq. Bio Medical Journal of Open Gastroenterology. 2015;3:e000067.

36. El-Sheredy AG, El-Kader OAM, ElGhazzawy EF, Helaly GF, El-Naggar AA, Mahadi MM. Occult hepatitis $B$ virus infection in patients with blood diseases. International Journal of Current
Microbiology and Applied Sciences. 2015; 4(1):1-10.

37. Lavanya V, Viswanathan $\mathrm{T}$, Malar SAS, Malarvizhi A, Moorthy A. Prevalence of Hepatitis B virus infection among blood donors with antibodies to hepatitis $B$ core Antigen. International Journal of Medicine and Medical Sciences. 2012;4(6): 128-137.

38. Joanah I, Okpara H, Elemi I, Ogarepe Y, Udoh E, Ekanem E. The prevalence of hepatitis B virus infection in Nigerian children prior to vaccine introduction into the National Programme on Immunization Schedule. Pan African Medical Journal. 2016;23:128:1-9.

39. Kurien T, Thyagarajan SP, Jeyaseelan L, Peedicayil A, Rajendran P, Sivaram S, Hansdak SG, Renu SG, Krishnamurthy P, Sudhakar K, Varghese JC. Community prevalence of hepatitis $B$ infection and modes of transmission in Tamil Nadu. Indian Journal of Medical Research. 2005;121(5):670-675.

40. Abdalwhab M, Nafi M. Sero-frequency of hepatitis B infection among healthcare workers in Khartoum. American Journal of Research Communication. 2014;2(12): $148-154$.

(c) 2017 Abimiku et al.; This is an Open Access article distributed under the terms of the Creative Commons Attribution License (http://creativecommons.org/licenses/by/4.0), which permits unrestricted use, distribution, and reproduction in any medium, provided the original work is properly cited.

Peer-review history:

The peer review history for this paper can be accessed here: http://sciencedomain.org/review-history/19434 